Vol 1. No 3. Juli 2021 P-ISSN : 2774-8022, e-ISSN : 2774-5791

\title{
HUBUNGAN KREATIVITAS DAN MOTIVASI BERPRESTASI DENGAN KOMPETENSI PEDAGOGIK GURU DI SMP NEGERI KECAMATAN PERBAUNGAN
}

\author{
DUSLI SINABUTAR \\ SMP Negeri Kecamatan Perbaungan Sumatera Utara \\ Email : duslisinabutar@gmail.com
}

\begin{abstract}
ABSTRAK
Penelitian ini bertujuan untuk mengetahui hubungan antara kreativitas dengan kompetens pedagogik guru di SMP Negeri Kecamatan Perbaungan selanjutnya untuk mengetahui hubungan antara motivasi berprestasi dengan kompetensi pedagogik guru di SMP Negeri Kecamatan Perbaungan dan untuk mengetahui hubungan antara kreativitas dan motivasi berprestasi secara bersama-sama dengan kompetensi pedagogik guru di SMP Negeri Kecamatan Perbaungan. Penelitian ini merupakan penelitian deskriptif korelasional. Populasi penelitian berjumlah 136 orang dan sampel berjumlah 51 orang. Hasil analisis data menunjukkan bahwa terdapat hubungan positif dan signifikan antara kreativitas dengan kompetensi pedagogik guru di SMP Negeri Kecamatan Perbaungan, terdapat hubungan signifikan antara motivasi berprestasi dengan kompetensi pedagogik guru di SMP Negeri Kecamatan Perbaungan, dan terdapat hubungan positif dan signifikan antara kreativitas dan motivasi berprestasi secara bersama-sama dengan kompetensi pedagogik guru di SMP Negeri Kecamatan Perbaungan. Kesimpulan hasil penelitian adalah terdapat hubungan positif dan signifikan antara kreativitas dan motivasi berprestasi secara sendiri-sendiri maupun secara bersama-sama dengan kompetensi pedagogik guru SMP Negeri Kecamatan Perbaungan.
\end{abstract}

Kata Kunci : Kreativitas, Motivasi Berprestasi, Kompetensi Pedagogik Guru

\section{PENDAHULUAN}

Kompetensi pedagogik merupakan salah satu dari empat kompetensi guru sebagai agen pembelajaran sebagaimana terdapat pada Peraturan Pemerintah No.19 Tahun 2005. Kompetensi pedagogik adalah kemampuan mengelola pembelajaran peserta didik yang meliputi pemahaman terhadap peserta didik untuk mengaktualisasikan berbagai potensi yang dimilikinya. Kompetensi pedagogik meliputi subkomponen pengelolaan pembelajaran dan subkomponen wawasan kependidikan. Kompetensi pengelolaan pembelajaran berkaitan dengan penyusunan rencana pembelajaran, pelaksanaan pembelajaran, penilaian prestasi belajar peserta didik, pelaksanaan tindak lanjut hasil penilaian prestasi belajar peserta didik. Kompetensi wawasan kependidikan meliputi pemahaman landasan pendidikan, pemahaman kebijakan pendidikan, pemahaman terhadap tingkat perkembangan siswa, pemahaman terhadap pendekatan pembelajaran yang sesuai dengan materi, pemahaman terhadap komunikasi dan kerja sama dalam pekerjaan dan pemanfaatan computer atau internet. Menurut Sudrajat (2008) peran dan tanggung jawab guru pada masa mendatang akan semakin kompleks sehingga menuntut guru untuk senantiasa melakukan berbagai peningkatan dan penyusuaian penguasaan kompetensinya. Guru harus lebih dinamis, kreatif dan harus paham penelitian untuk mendukung terhadap efektivitas pembelajaran yang dilaksanakannya.

Menurut Sagala (2009:159) pengalaman menunjukkan bahwa : Profil guru yang tidak menggunakan pendekatan pedagogik dalam melakukan pembelajaran peserta didik antara lain: (1) guru lebih banyak menggunakan metode ceramah sehingga interaksi searah; (2) media belum dimanfaatkan; (3) pengelolaan belajar cenderung klasikal dan kegiatan belajar kurang bervariasi; (4) tuntutan pendidik terhadap hasil belajar dan produktivitas rendah. Pembelajaran yang selama ini berpusat pada guru, harus diubah menjadi berpusat pada peserta didik. Pendidik mengedepankan metode-metode pemahaman dan penemuan sebagai syarat untuk memenuhi kompetensi. Oleh karena itu kemampuan profesi pendidik perlu ditingkatkan dengan memantapkan kemampuan pedagogik. 
Menurut Sarimaya (2008:19) kompetensi pedagogik terdiri dari 5 subkompetensi yang selanjutnya dijabarkan dalam indikator utama sebagai berikut: (1) subkompetensi memahami peserta didik secara mendalam memiliki indikator utama; memahami peserta didik dengan memanfaatkan prinsip-prinsip perkembangan kognitif; memahami peserta didik dengan memanfaatkan prinsip-prinsip kepribadian; dan mengidentifikasi bekal ajar awal peserta didik; (2) subkompetensi merancang pembelajaran, termasuk memahami landasan pendidikan untuk kepentingan pembelajaran memiliki indikator utama; memahami landasan kependidikan; menerapkan teori belajar dan pembelajaran; menentukan strategi pembelajaran berdasarkan karakteristik peseta didik, kompetensi yang ingin dicapai, dan materi ajar serta menyusun rancangan pembelajaran berdasarkan strategi yang dipilih; (3) subkompetensi melakukan pembelajaran memiliki indikator utama; menata latar pembelajaran; melaksanakan pembelajaran yang kondusif; (4) subkompetensi merancang dan melaksanakan evaluasi pembelajaran memilih indikator utama; merancang dan melaksanakan evaluasi proses dan hasil belajar secara berkesinambungan dengan berbagai metode; menganalisis hasil evaluasi proses dan hasil belajar untuk menentukan tingkat ketuntasan belajar; dan memanfaatkan hasil penilaian pembelajaran untuk perbaikan kualitas program pembelajaran secara umum; (5) subkompetensi mengembangkan peserta didik untuk mengaktualisasikan berbagai potensinya, memiliki indikator utama: memfasilitasi peserta didik untuk mengembangkan berbagai potensi akademik dan non akademik

\section{Hakikat Kompetensi Pedagogik Guru}

Menurut Uno (2007:80) mengatakan kompetensi guru merupakan kapasitas internal yang dimiliki guru dalam melaksanakan tugas profesinya. Menurut Sagala (2009:158) kompetensi pedagogik adalah kemampuan pendidik menciptakan suasana dan pengalaman belajar bervariasi dalam pengelolaan peserta didik yang memenuhi kurikulum yang disiapkan yaitu bagaimana pendidik : 1) Memiliki pemahaman wawasan atau landasan; 2) Memiliki pemahaman terhadap peserta didik; 3) Mampu mengembangkan kurikulum/silabus; 4) Mampu menyusun rancangan pembelajaran yang mendidik dan dialogis; 5) Melakukan evaluasi hasil belajar dengan prosedur yang benar; dan 6) Mampu mengembangkan potensi peserta didik untuk mengaktualisasikan berbagai potensi yang dimilikinya.

\section{Hakikat Kreativitas}

Menurut Mulyasa (2007:51) mengatakan kreativitas ditandai oleh adanya kegiatan menciptakan sesuatu yang sebelumnya tidak ada dan tidak dilakukan oleh seseorang atau adanya kecenderungan untuk menciptakan sesuatu. Menurut Meiner (2005:307) kreativitas berarti berkreasi terus menerus, maka menjadi seorang ahli pembelajaran yang bertanggungjawab masa sekarang berarti mengasah kreativitas meskipun sesekali timbul penghambat dari lingkungan. Lebih lanjut De Porter dan Hernacki (2005:292) menyatakan bahwa kreativitas adalah suatu usaha untuk menemukan jalan keluar ketika menghadapi masalah.

\section{Hakikat Motivasi Berprestasi}

Menurut Mangkunegara (2006:67) mengemukakan bahwa motivasi berprestasi sebagai suatu dorongan dalam diri seseorang untuk melakukan atau mengerjakan sesuatu kegiatan atau tugas dengan sebaik-baiknya agar mencapai prestasi dengan predikat terpuji. Seseorang dapat dikatakan memilki karakteristik motivasi berprestasi tinggi bila memiliki tanggung jawab pribadi yang tinggi, berusaha mencari umpan balik atas segala perbuatannya, memilki kemampuan untuk mengambil keputusan dan berani mengambil resiko dengan penuh perhitungan, berusaha melakukan sesuatu secara inovatif dan kreatif, mampu menggunakan waktu sebaik mungkin, bekerja keras dan bangga atas hasil dicapai (Usman, 2006:238). 


\section{B. Hasil Penelitian yang Relevan}

Penelitian Rahmanizar (2006) tentang Hubungan Persepsi Guru Tentang Kepemimpinan Kepala Madrasah dan Motivasi Berprestasi dengan Keprofesionalan Guru Madrasah Aliyah Negeri (MAN) di Kota Tanjung Balai menyimpulkan bahwa terdapat hubungan antara motivasi berprestasi dengan keprofesionalan guru. Selanjutnya Abubakar (2007) meneliti tentang Hubungan antara Motivasi Berprestasi dan Iklim Kerja terhadap Kinerja Guru SMP Negeri di Kota Kendari menyimpulkan bahwa terdapat hubungan motivasi berprestasi dengan kinerja guru SMP Negeri di Kota Kendari. Kemudian penelitian yang dilakukan oleh Sitompul (2007) tentang Hubungan antara Kreativitas dan Motivasi Berprestasi dengan Pemanfaatan Lingkungan Sebagai Sumber Belajar di Sekolah Dasar Negeri Kecamatan Pancur Batu menyimpulkan bahwa terdapat hubungan antara kreativitas kerja dengan kemampuan memanfaatkan lingkungan sebagai sumber belajar dan terdapat hubungan antara motivasi berprestasi dengan kemampuan memanfaatkan lingkungan sebagai sumber belajar.

\section{Kerangka Berpikir}

\section{Hubungan Kreativitas dengan Kompetensi Pedagogik Guru}

Dalam mengembangkan kompetensi pedagogik seorang guru membutuhkan kemampuan berpikir kreatif untuk menghasilkan ide-ide atau gagasan- gagasan baru dalam proses belajar- mengajar yang akan membawa perbaikan pada kualitas pembelajaran. Kreativitas dianggap sebagai salah satu sarana yang diambil oleh seorang guru untuk mengaktualisasikan dirinya. Guru yang memiliki kreativitas tentu saja mampu mengatasi permasalahan yang dihadapi dalam melaksanakan tugasnya. Berdasarkan analisis diatas, diduga bahwa jika guru memiliki kreativitas diyakini akan mempunyai hubungan dengan kompetensi pedagogik guru. Guru yang memiliki kreativitas yang tinggi pada gilirannya guru tersebut mampu menciptakan pembelajaran yang menarik dan tidak membosankan bagi peserta didik.

\section{Hubungan Motivasi Berprestasi dengan Kompetensi Pedagogik Guru}

Guru yang memiliki motivasi tercermin melalui ketekunan dalam menjalankan tugas yakni melaksanakan proses belajar-mengajar yang selalu mengembangkan dan melatih keterampilan serta bekerjasama dengan rekan guru untuk mencapai keberhasilan pembelajaran peserta didik. Guru akan melengkapi perangkat pembelajaran yang dirancang sesuai dengan ketentuan yang berlaku, dan termotivasi untuk melaksanakan perubahan untuk perbaikan kualitas pembelajaran yang pada gilirannya akan meningkatkan kompetensi pedagogik guru. Berdasarkan analisis diatas, diduga bahwa jika guru memiliki motivasi berprestasi diyakini akan mempunyai hubungan dengan kompetensi pedagogik guru. Guru yang memiliki motivasi berprestasi, maka guru tersebut akan menjalankan tugas dengan penuh tanggungjawab, seperti

dalam melaksanakan kegiatan pembelajaran dikelas, mengikuti pelatihan-pelatihan untuk meningkatkan keterampilan, dan membina hubungan baik atau bekerjasama dengan sesama guru untuk meningkatkan kompetensi.

\section{Hubungan Kreativitas dan Motivasi Berprestasi Secara Bersama-sama dengan Kompetensi Pedagogik Guru}

Guru yang memiliki kreativitas dan motivasi berprestasi yang tinggi diyakini akan memiliki kompetensi yang tinggi pula. Motivasi berprestasi sebagai suatu keinginan dalam berbuat untuk mencapai keberhasilan yang terwujud melalui pelaksanaan kegiatan yang mengarah kepada tujuan yang telah ditetapkan. Kompetensi pedagogik adalah kemampuan pengelola pembelajaran peserta didik yang meliputi pemahaman terhadap peserta didik, perancang, dan pelaksanaan pembelajaran, evaluasi hasil belajar, dan pengembangan peserta didik untuk mengaktualisasikan berbagai potensi yang dimilikinya.

Berdasarkan analisis diatas, diduga bahwa jika guru memiliki kreativitas dan motivasi 
berprestasi diyakini akan mempunyai hubungan dengan kompetensi pedagogik guru. Guru yang memiliki kreativitas dan motivasi berprestasi yang tinggi, maka guru tersebut akan berkompeten.

\section{METODOLOGI PENELITIAN}

Penelitian ini adalah untuk mengetahui hubungan kreativitas dan motivasi berprestasi dengan kompetensi pedagogik guru di SMP Negeri Kecamatan Perbaungan. Metode yang digunakan dalam penelitian ini adalah teknik analisis korelasi dan regresi dengan menggunakan pendekatan deskriptif kuantitatif.

Populasi dalam penelitian ini adalah seluruh guru SMP Negeri di Kecamatan Perbaungan tahun pelajaran 2008/2009 yang berjumlah 136 orang. Pengambilan sampel dilakukan dengan menggunakan stratified proportional random sampling dengan menggunakan rumus cochran. Maka diperoleh sampel sebesar 51 orang. Dalam menjaring data menggunakan kuisioner model skala linkert. Selanjutnya untuk mengetahui kuisioner yang dibuat cukup sahih dan handal, maka dilakukan uji coba kepada responden dan di analisis menggunakan teknik korelasi Product Momen dengan taraf signifikansi sebesar $\alpha=0,05$ (Arikunto, 2002:146), dan apakah butir item yang disusun sudah reliable maka digunakan dengan rumus Alpa Cronbarch. Analisis data dilakukan menggunakan teknik korelasi dan regresi linier sederhana dan ganda, serta korelasi parsial. Penguji persyaratan analisis dengan uji normalitas menggunakan uji Lilliefors (Sujana, 2005:466) dan uji linieritas garis dengan teknik regresi sederhana (Sujana, 2005:330).

Pengujian hipotesis yaitu hipotesis pertama dan kedua dilakukan dengan teknik korelasi sederhana dan regresi sederhana. Penelitian hipotesi ketiga dilakukan dengan teknik korelasi ganda dan regresi ganda.

\section{HASIL PENELITIAN DAN PEMBAHASAN}

\section{Hasil Penelitian}

Berdasarkan hasil penelitian dan analisis regresi sederhana ditunjukkan oleh persamaan garis sederhana $=48,41+0,58 \mathrm{X}_{1}$ adalah linier dan berarti pada taraf signifikansi $(\alpha)=0,05$. Karena harga $F_{\text {hitung }}>F_{\text {tabel }}$, maka dapat disimpulkan bahwa koefisien arah regresi $Y$ atas $\mathrm{X}_{1}$ adalah berarti. Dapat dilihat pada tabel 1.

Tabel 1. Rangkuman Uji Linieritas Kompetensi Pedagogik atas Kreativitas

\begin{tabular}{|c|c|c|c|c|c|}
\hline $\begin{array}{c}\text { Sumber } \\
\text { Variabel }\end{array}$ & d k & $\begin{array}{c}\text { Jumlah } \\
\text { Kuadrat (JK) }\end{array}$ & $\begin{array}{c}\text { Rata- Rata } \\
\text { Jumlah } \\
\text { Kuadrat } \\
\text { (RJK) }\end{array}$ & Fhitung & Ftabel \\
\hline Total & 51 & 532339 & - & - & - \\
\hline $\begin{array}{c}\text { Koefisien (a) } \\
\text { Regresi i } \\
\text { (b/a) }\end{array}$ & 11 & 527548,41 & 1707 & 27,2 & 4,0 \\
$\begin{array}{c}\text { Residu } \\
\text { Tuna Cocok } \\
\text { (TC) }\end{array}$ & 31 & 1743,48 & 51 & 2 & 4 \\
Galat (G) & 18 & 1329,41 & $\begin{array}{c}56,24 \\
73,85\end{array}$ & 0,76 & 2,11 \\
\hline
\end{tabular}


Berdasarkan hasil uji linieritas diperoleh $F_{\text {hitung }}<F_{\text {tabel }}$ yaitu $0,76<2,11$ dan uji disimpulkan arah regresi diperoleh $F_{\text {hitung }}>F_{\text {tabel }}$ aitu sehingga dapat disimpulkan bahwa persamaan $=+0,58 \mathrm{X}_{1}$ adalah linier dan berarti pada taraf signifikansi $(\alpha)=5$. Dari uji keberartian koefisien korelasi dengan uji $\mathrm{T}$ diperoleh $\mathrm{T}_{\text {hitung }}$ sebesar 5,21, jika nilai $\mathrm{T}_{\text {hitung }}$ ini dibandingkan dengan nilai $\mathrm{T}_{\text {tabel }}$ dengan $\mathrm{db}$ 51-2 $=49$ diperoleh pada taraf signifikansi $(\alpha)=$ 5. Karena $\mathrm{T}_{\text {hitung }}>\mathrm{T}_{\text {tabel }}$ yaitu 5,21 $>2,011$. Maka dapat disimpulkan bahwa $\mathrm{H}_{0}$ ditolak dan $\mathrm{H}_{\mathrm{a}}$ diterima. Dengan demikian hipotesis yang berbunyi "terdapat hubungan yang positif dan signifikan antara kreativitas dengan kompetensi pedagogik guru di SMP Negeri Kecamatan Perbaungan" teruji kebenarannya, artinya semakin tinggi kualitas kreativitas yang dilakukan guru maka semakin tinggi pula kualitas kompetensi pedagogik guru tersebut. Ringkasan hasil perhitungan hipotesis pertama ini dapat dilihat pada tabel 2.

Tabel 2. Rangkuman ANAVA Keberartian Regresi $Y$ atas $X_{1}$

\begin{tabular}{|c|c|c|c|c|c|}
\hline $\begin{array}{c}\text { Sumber } \\
\text { Varians }\end{array}$ & dk & $\begin{array}{c}\text { Jumlah } \\
\text { Kuadrat (JK) }\end{array}$ & $\begin{array}{c}\text { Rata- Rata Jumlah } \\
\text { Kuadrat(RJK) }\end{array}$ & Fhitung & Ftabel \\
\hline Regresi & 14 & 1707,51 & 1707,51 & 27,222 & 4,04 \\
Residu & 9 & 3073,07 & 62,71 & & \\
\hline Total & 50 & 4780,58 & \multicolumn{2}{|l}{} \\
\hline
\end{tabular}

Berdasarkan Tabel diatas dapat dilihat bahwa $F_{\text {hitung }}$ yang diperoleh sebesar 27,22 sedangkan harga $F_{\text {tabel }}$ dengan $\mathrm{db}(1,49)$ diperoleh sebesar 4,04. Oleh karena $F_{\text {hitung }}>F_{\text {tabel }}$ yaitu 27,22> 4,04 maka persamaan garis regresi sederhana yang dibentuk oleh variabel kreativitas dengan kompetensi pedagogik guru di SMP Negeri Kecamatan Perbaungan memiliki keberartian apabila didekati dengan persamaan regresi pada taraf signifikansi 5 yaitu $=0,58$ $\mathrm{X}_{1}$. Persamaan regresi ini dapat digunakan memprediksi varians yang terjadi pada kompetensi pedagogik guru di SMP Negeri Kecamatan Perbaungan melalui prediktor kreativitas.

Berdasarkan hasil analisis korelasi $\mathrm{X}_{2}$ dengan Ydiketahui bahwa koefisien korelasi sebesar $r=0.46$, dengan uji keberartian koefisien korelasi dengan uji $t$ diperoleh $t_{h i t u n g}$ sebesar 3.65. Jika nilai $t-$ hitung ini dibandingkan dengan nilai $t_{\text {tabel }}$ dengan $\mathrm{db}=15-2=49$ diperoleh besaran pada taraf signifikansi $(\alpha)=.5$ maka terlihat abhwa $t_{\text {hitung }}>t_{\text {tabel }}$ yakni $3.65>$ 2.011, maka dapat disimpulkan bahwa $\mathrm{H}_{0}$ di tolak dan $\mathrm{H}_{\mathrm{a}}$ di terima.

Dengan demikian hipotesa ang berbun i persamaan garis $=.02+0.52 \mathrm{X}_{2}$ memberi makna jika motivasi berprestasi dapat ditingkatkan sebesar satu unit, maka kompetensi pedagogik guru di SMP Negeri Kecamatan Perbaungan akan meningkat sebesar 0.50 dengan intersep 66.2. Terdapat hubungan positif dan signifikan antara motivasi berprestasi dengan kompetensi pedagogik guru di SMP Negeri Kecamatan Perbaungan teruji kebenarannya. Artinya, semakin tinggi kualitas motivasi berprestasi yang dilakukan oleh guru, maka semakin tinggi pula kualitas kompetensi pedagogik guru tersebut. Ringkasan hasil perhitungan hipotesis kedua ini dapat dilihat pada tabel 3

Tabel 3. Rangkuman ANAVA Keberartian Regresi $Y$ atas $X_{2}$

\begin{tabular}{|c|c|c|c|c|c|}
\hline $\begin{array}{c}\text { Sumber } \\
\text { Varians }\end{array}$ & dk & $\begin{array}{c}\text { Jumlah } \\
\text { Kuadrat (JK) }\end{array}$ & $\begin{array}{c}\text { Rata-Rata Jumlah } \\
\text { Kuadrat(RJK) }\end{array}$ & Fhitung & Ftabel \\
\hline Regresi & 14 & 1026.20 & 1026.20 & 13.39 & 4.04 \\
Residu & 9 & 3754.38 & 62.71 & & \\
\hline Total & 50 & 4780.5 & \multicolumn{2}{|l}{} \\
\hline
\end{tabular}

Berdasarkan Tabel di atas dapat dilihat bahwa $F_{\text {hitung }}$ yang diperoleh sebesar 13.39, 
sedangkan harga $F_{\text {tabel }}$ dengan db (1.49) diperoleh sebesar 4.04 oleh karena $F_{\text {hitung }}>F_{\text {tabel }}$ yaitu $13.39>4.04$ maka persamaan garis regresi sederhana yang dibentuk oleh variabel motivasi berprestasi dengan kompetensi pedagogik guru di SMP Negeri Kecamatan Perbaungan memilki keberartian apabila didekati dengan persamaan regresi pada taraf signifikansi 0.05 yaitu 0.50 $\mathrm{X}_{2}$. Persamaan garis ini dapat digunakan memprediksi varians yang terjadi pada kompetensi pedagogik guru di SMP Negeri Kecamatan Perbaungan melalui prediktor motivasi berprestasi.

Untuk menguji hipotesis ketiga digunakan analisis dan regresi ganda. Hasil analisis dari perhitungan diperoleh koefisien korelasi sebesar $\mathrm{R}=0.70$ dengan koefisien determinasi mencapai $\mathrm{R}^{2}=0.49$. Berdasarkan hasil analisis $\mathrm{X}_{1}$ dan $\mathrm{X}_{2}$ dengan $\mathrm{Y}$ diketahui bahwa variabel kreativitas dan motivasi berprestasi secara bersama-sama dengan kompetensi pedagogik guru di SMP Negeri Kecamatan Perbaungan menunjukkan bahwa koefisien korelasi sebesar 0.70 yang menujukkan hubungan kuat kreativitas dan motivasi berprestasi secara bersama-sama dengan kompetensi pedagogik guru, dan besar koefisien determinasi yang diperoleh yaitu 0.49. Besar koefisien ini juga memberikan makna bahwa terdapat hubungan positif dan signifikan antara kreativitas dan motivasi berprestasi secara bersama-sama dengan kompetensi pedagogik guru di SMP Negeri Kecamatan Perbaungan, besarnya presentasi bobot hubungan yang diperoleh adalah $0.49 \times 100 \%=49 \%$. Sedangkan sisanya sebesar $51 \%$ lagi diperkirakan berasal dari faktor-faktor lain yang tidak termasuk dalam penelitian ini.

Berdasarkan hasil yang diperoleh koefisien regresi ganda antara kreativitas dan motivasi berprestasi dengan kompetensi pedagogik guru di SMP Negeri ecamatan erbaungan diperoleh persamaan $=5.5_{1}+0.40 \mathrm{X}_{2}$ dapat dilihat pada tabel 4 .

Tabel 4. Ringkasan ANAVA Keberartian Regresi $Y$ atas $X_{1}$ dan $X_{2}$

\begin{tabular}{|l|c|c|c|c|c|}
\hline $\begin{array}{c}\text { Sumber } \\
\text { Varians }\end{array}$ & dk & $\begin{array}{c}\text { Jumlah } \\
\text { Kuadrat (JK) }\end{array}$ & $\begin{array}{c}\text { Rata-Rata Jumlah } \\
\text { Kuadrat (RJK) }\end{array}$ & Fhitung & $\begin{array}{c}\text { Ftabel pada } \\
\boldsymbol{\alpha}=\mathbf{0 . 0 5}\end{array}$ \\
\hline Regresi & 2 & 2354.91 & 1177.45 & 23.29 & 3.19 \\
Residu & 48 & 2425.67 & 50.53 & & \\
\hline \multicolumn{1}{c|}{ Total } & 50 & 4780.58 & & & \\
\hline
\end{tabular}

Berdasarkan tabel diatas didapat $F_{\text {hitung }}$ sebesar 23.29, sedangkan $F_{\text {tabel }}$ pada dk (3.19) $\alpha=5$ sebesar 3.9 jadi $F_{h i t u n g}>F_{\text {tabel }}$ yakni $23.29>3.19$, maka dapat disimpulkan bahwa persamaan garis regresi ganda yang dibentuk oleh variabel kreativitas dan motivasi berprestasi secara bersama-sama dengan kompetensi pedagogik guru di SMP Negeri Kecamatan Perbaungan memiliki keberartian apabila didekati dengan persamaan regresi pada taraf signifikansi 5 y aitu $=5.0 .52 \mathrm{X}_{1}+0.40 \mathrm{X}_{2}$. Persamaan regresi tersebut, dapat juga dijelaskan bahwa dengan peningkatan kreativitas dan motivasi berprestasi secara bersama-sama sebesar satu unit, maka kompetensi pedagogik di SMP Negeri Kecamatan Perbaungan akan meningkat sebesar $0.52+0.40=0.93$ unit. Hal ini memberikan makna bahwa semakin baik kreativitas dan motivasi berprestasi secara bersama-sama akan semakin baik pula kompetensi pedagogik guru di SMP Negeri Kecamatan Perbaungan.

Selanjutnya untuk mengetahui seberapa besar bobot sumbangan masing- masing variabel bebas yaitu kreativitas dan motivasi berprestasi dengan kompetensi pedagogik guru di SMP Negeri Kecamatan Perbaungan dapat dilihat pada tabel 5 berikut ini. 
Tabel 5. Rangkuman Bobot Sumbangan Variabel $X_{1}$ dan $X_{2}$

\begin{tabular}{|c|c|c|}
\hline Variabel Bebas & Sumbangan Relatif (\%) & Sumbangan Efektif (\%) \\
\hline $\begin{array}{c}\text { Kreativitas }\left(\mathrm{X}_{1}\right) \\
\text { Motivasi Berprestasi }\end{array}$ & 64.89 & 31.96 \\
$\left(\mathrm{X}_{2}\right)$ & 35.11 & 17.30 \\
\hline Total & 100.00 & 49.26 \\
\hline
\end{tabular}

Berdasarkan tabel 5 diatas, menunjukkan bahwa terdapat hubungan antara variabel kreativitas $\left(\mathrm{X}_{1}\right)$ dengan kompetensi pedagogik $(\mathrm{Y})$ pada saat variabel motivasi berprestaso $\left(\mathrm{X}_{2}\right)$ dikontrol sebesar 0.95 dan koefisien determinasi 0.35 artinya kreativitas memberikan sumbangan sebesar $31.96 \%$ terhadap kompetensi pedagogik guru, bila $\mathrm{X}_{2}$ dalam keadaan konstan atau dikontrol. Demikian juga hubungan antara variabel motivasi berprestasi $\left(\mathrm{X}_{2}\right)$ dengan kompetensi pedagogik $(\mathrm{Y})$. Jika variabel $\mathrm{X}_{1}$ dikontrol, koefisien korelasinya 0.45 dan koefisien determinasinya 0.21 . Artinya motivasi berprestasi memberikan sumbangan kompetensi pedagogik guru sebesar $.3 \%$ pada taraf signifikansi $(\alpha)=0.05$. Hasil analisis ini menunjukkan bahwa kreativitas dan motivasi berprestasi merupakan faktor yang dapat memberikan dampak positif terhadap meningkatnya kompetensi pedagogik guru.

\section{Pembahasan}

Berdasarkan hasil analisis data penelitian yang telah dilakukan sebelumnya, menunjukkan bahwa ketiga hipotesis yang diajukan oleh peneliti teruji secara empiris.

\section{Hubungan Kreativitas dengan Kompetensi Pedagogik Guru}

Temuan pertama penelitian ini menunjukkan bahwa kreativitas berkorelasi positif dan signifikan dengan kompetensi pedagogik guru di SMP Negeri Kecamatan Perbaungan dengan besar koefisien korelasi parsial $\mathrm{r}=0.59$ yang menunjukkan hubungan sedang antara kreativitas dengan kompetensi pedagogik guru sedangkan sumbangan efektifnya $31.96 \%$. Kreativitas yang ditunjukkan oleh guru merupakan faktor yang penting dan turut menentukan bagi peningkatan kompetensi pedagogik guru. Kreativitas guru dalam penelitian ini merupakan kemampuan guru untuk menciptakan sesuatu yang baru dalam meningkatkan kegiatan mengelola proses belajar-mengajar.

Menurut Slamet (2007:7) bahwa salah satu komponen mengelola pembelajaran peserta didik adalah melaksanakan pembelajaran yang pro-perubahan (aktif, kreatif, inovatif, eksperimental, efektif dan menyenangkan), menilai hasil belajar peserta didik secara otentik yang mencakup aspek kognitif, afektif dan psikomotornya. Oleh sebab itu, pembelajaran yang pro-perubahan hanya akan bisa terwujud apabila guru itu sendiri memiliki kreativitas yang tinggi. Menurut Widayati (2002:21), yang mengemukakan bahwa kreativitas adalah suatu potensi berpikir yang dimiliki semua orang. De Porter dan Hernacki (2005:292) mengemukakan bahwa kreativitas adalah suatu usaha untuk menemukan jalan keluar ketika menghadapi masalah.

Temuan penelitian ini menunjukkan bahwa kreativitas yang dimiliki oleh guru akan mendorongnya untuk mengembangkan kemampuan mengelola pembelajaran peserta didik yang mendidik melalui penterjemahan kurikulum yang lebih baik dan berkualitas. Hal tersebut mendukung pendapat Craft (2000:23) yang mengatakan seorang guru kreatif akan menstimulasi dan mendorong pikiran yang berdaya dalam mensikapi kurikulum dengan cara yang beranekaragam. Semakin tinggi kreativitas guru maka diyakini akan semakin meningkat pula kompetensi pedagogiknya.

\section{Hubungan Motivasi Berprestasi dengan Kompetensi Pedagogik}


Temuan kedua dalam penelitian ini menunjukkan bahwa terdapat hubungan positif dan signifikan antara motivasi berprestasi dengan kompetensi pedagogik guru di SMP Negeri Kecamatan Perbaungan dengan besar koefisien korelasi parsial $r=0.45$ yang menunjukkan hubungan sedang diantara keduanya, sedangkan sumbangan efektifnya $17.3 \%$. Kendatipun sumbangan efektifnya masih tergolong kecil namun setidaknya temuan ini dapat mengungkap secara empiris bahwa untuk meningkatkan kompetensi pedagogik guru. Salah satu faktor yang mempengaruhinya adalah motivasi berprestasi yang dimiliki oleh guru.

Motivasi berprestasi adalah motif untuk mengarahkan tingkah laku seseorang dengan titik berat bagaimana prestasi tersebut tercapai. Guru yang memiliki motivasi tercermin melalui ketekunan dalam menjalankan tugas yakni melaksanakan proses belajar mengajar yang selalu mengembangkan dan melatih keterampilan serta bekerjasama dengan rekan guru untuk mencapai pembelajaran peserta didik. Melalui penerapan motivasi berprestasi yang tinggi oleh guru SMP Negeri Kecamatan Perbaungan, akan memberikan dampak positif terhadap peningkatan kompetensi pedagogik di SMP Negeri Kecamatan Perbaungan.

Hasil penelitian juga relevan dengan penelitian Rahmanizar (2006) tentang Hubungan Persepsi Guru Tentang Kepemimpinan Kepala Madrasah dan Motivasi Berprestasi dengan Keprofesionalan Guru Madrasah Aliyah Negeri (MAN) di Kota Tanjung Balai menyimpulkan bahwa terdapat hubungan antara motivasi berprestasi dengan keprofesionalan guru Madrasah Aliyah Negeri (MAN) di Kota Tanjung Balai. Dengan demikian maka motivasi berprestasi akan meningkatkan profesionalisme guru. Salah satu kompetensi yang dimiliki seorang guru profesionalisme adalah kompetensi pedagogik.

Temuan ini juga memberi penegasan kepada hasil penelitian yang dilakukan oleh Abubakar (2007) meneliti tentang Hubungan antara Motivasi Berprestasi dan Iklim Kerja terhadap Kinerja Guru SMP Negeri di Kota Kendari menyimpulkan bahwa terdapat hubungan motivasi berprestasi dengan kinerja guru SMP Negeri di Kota Kendari. Artinya, motivasi berprestasi akan mendorong meningkatkan kompetensi pedagogik yang dimiliki oleh guru sehingga kinerja yang ditunjukkannya akan semakin meningkat pula.

\section{Hubungan Antara Kreativitas dan Motivasi Berprestasi Secara Bersama- samaDengan Kompetensi Pedagogik Guru}

Temuan penelitian yang ketiga menunjukkan bahwa terdapat hubungan positif dan signifikan antara kreativitas dan motivasi berprestasi secara bersama-sama dengan kompetensi pedagogik guru di SMP Negeri Kecamatan Perbaungan. Hubungan yang kuat antara kreativitas dan motivasi berprestasi secara bersama-sama dengan kompetensi pedagogik ditunjukkan dengan koefisien sebesar 0.70 . Hal ini menunjukkan semakin tinggi kreativitas dan motivasi berprestasi secara bersama- sama maka akan semakin tinggi pula kompetensi pedagogik guru. Djiwandono (2002:17) menyatakan empat kompetensi guru yang efektif dalam mencapai hasil belajar yang diharapkan yaitu : 1) memiliki pengetahuan tentang belajar dan tingkah laku manusia; 2) menunjukkan sikap membantu siswa belajar dan memupuk hubungan dengan manusia secara tulus; 3) menguasai mata pelajaran yang diajarkan; dan 4) mengontrol keterampilan teknik mengajar sehingga memudahkan siswa belajar. Penelitian ini mendukung hasil penelitian yang dilakukan oleh Sitompul (2007) yang menyimpulkan bahwa terdapat hubungan antara kreativitas dan motivasi berprestasi secara bersama-sama dengan kemampuan memanfaatkan lingkungan sebagai sumber belajar disekolah dasar negeri kecamatan Pancur Batu.

Besarnya sumbangan efektif variabel kreativitas dan motivasi berprestasi secara bersama-sama dengan kompetensi pedagogik guru sebesar $49 \%$. Dari temuan penelitian diatas, variabel kreativitas dan motivasi berprestasi sangat berperan untuk meningkatkan kompetensi pedagogik guru secara bersama-sama.

\section{KESIMPULAN}


Temuan penelitian ini menunjukkan bahwa terdapat hubungan positif dan signifikan kreativitas dan motivasi berprestasi dengan kompetensi pedagogik guru di SMP Negeri Kecamatan Perbaungan. Sumbangan efektif kreativitas $31.9 \%$, sumbangan efektif motivasi berprestasi $17.30 \%$. Besar total sumbangan yang diberikan ditunjukkan dengan besaran koefisien determinasi mencapai $49 \%$. Hal ini memberi kesimpulan umum bahwa kreativitas dan motivasi berprestasi merupakan faktor yang memiliki korelasi atau menentukan dalam peningkatan kompetensi pedagogik guru di SMP Negeri Kecamatan Perbaungan.

\section{DAFTAR PUSTAKA}

Abubakar, S. R. (2007). Hubungan Antara Motivasi Berprestasi dan Iklim Kerja Terhadap Kinerja Guru SMP Negeri di Kota Keendari. Dipetik Mei 5, 2009, dari http;//lpmpsultra.net/index.php?opt ion=com/.

Arikunto, S. (2002). Prosedur Penelitian, Suatu Pendekatan Praktek. Jakarta: Rineka Cipta.

Craft, A. (2000). Membangan Kreativitas Anak, Terjemahan oleh M. Chairul Annam. Jakarta: Inisiasi Press.

Djiwandono, S. E. (2002). Psikologi Pendidikan. Jakarta: Gramedia.

Hernacki, D. P. (2005). Quantum Learning. Bandung: Kaifa.

Meir, D. (2005). The Accelerated Learning Hand Book. Bandung: Kaifa.

Mulyasa, E. (2007). Menjadi Guru Profesional Menciptakan Pembelajaran Kreatif dan Menyenangkan . Bandung: Remaja Rosdakarya.

Peraturan Pemerintah Republik Indonesia Nomor 19 tahun 2005 tentang Standar Nasional Pendidikan. Jakarta: BNSP.

Prabu, M. A. (2006). Evaluasi Kinerja SDM. Bandung: Aditama.

Rahmanizar. (2006). Hubungan Persepsi Guru Tentang Kepemimpinan Kepala Madrasah dan Motivasi Berprestasi dengan Keprofesionalan Guru Madrasah Aliyah Negeri (MAN) di Kota Tanjung Balai. Medan: Program Pasca Sarjana Universitas Negeri Medan.

Sagala, S. (2009). Kemampuan Profesional Guru dan Tenaga Kependidikan . Bandung: Alfabeta.

Sarimaya, F. (2008). Sertifikasi Guru. Bandung: Yrama Widya.

Sitompul, R. (2007). Hubungan antara Kreativitas dan Motivasi Berprestasi dengan Pemanfaatan Lingkungan sebagai Sumber Belajar di Sekolah Dasar Negeri Kecamatan Pancur Batu. Medan: Program Pasca Sarjana Universitas Negeri Medan.

Slamet. (2007). Strategi Pencapaian Kompetensi Dalam Rangka Menghadapi Uji Sertifikasi Guru dan Dosen. Medan: Lembaga Pengabdian Kepada Masyarakat Universitas Negeri Medan.

Sri C Widayati, d. (2002). Reformasi Pendidikan Dasar. Jakarta: Grasindo.

Sudjana. (2005). Metode Statistik. Bandung: Parsito.

Sudrajat, A. (2008). Kompetensi Guru dan Peran Kepala Sekolah. Dipetik Febuari 6, 2009, dari http://www.akhmatsudrajat.wordpr ess.com

Uno, H. B. (2007). Teori Motivasi dan Pengukurannya . Jakarta: Bumi Aksara.

Usman, H. (2006). Manajemen Teori, Praktik, dan Riset Pendidikan. Jakarta: Bumi Aksara. 